\title{
Assessment of heavy metal contamination in the drinking water of muzaffarabad, Azad Jammu and Kashmir, Pakistan
}

\begin{abstract}
Safe and good quality potable water is a basic requirement for human existence, but if polluted can become the source of substances dangerous to human health. Azad Jammu and Kashmir is facing the problem of low quality of drinking water like other neighboring regions. Present study aimed to evaluate the heavy metal status in the drinking water of Muzaffarabad and outlying areas. Fifty three water samples were collected randomly from taps and spring waters of the study area and analyzed for six heavy metals (Copper, chromium, manganese, lead and zinc). Concentration of $\mathrm{Cu}, \mathrm{Fe}, \mathrm{Mn}$ and $\mathrm{Zn}$ were below the guideline values of WHO and GOP. Chromium and lead exceeded standard values of WHO and GOP in $21 \%(\mathrm{n}=11)$ in each case. Overall $66 \%$ water samples were found potable, while in $33 \%$ samples heavy metal contamination surpassed permissible limit. The assessment shows quite a reasonable situation regarding heavy metal quality status of potable water.
\end{abstract}

Keywords: drinking water, heavy metal, muzaffarabad, AJ\&K
Volume 3 Issue 5 - 2019

\author{
Usman Ali, ${ }^{1,2}$ Aniqa Batool,' Muhammad Asad \\ Ghufran, ${ }^{3}$ Syeda Sabahat Kazmi, ${ }^{4}$ Syeda Hina \\ Fatimah $^{5}$ \\ 'Department of Environmental Sciences, Pir Mehr Ali Shah-Arid \\ Agriculture University Rawalpindi, Pakistan \\ ${ }^{2}$ Department of Zoology, Mirpur University of Science and \\ Technology, Mirpur, AJ\&K, Pakistan \\ ${ }^{3}$ Department of Environmental Sciences, International Islamic \\ University Islamabad, Pakistan \\ ${ }^{4}$ National Physical and Standardization Laboratories, Islamabad, \\ Pakistan \\ ${ }^{5}$ Department of Environmental Sciences, Allama lqbal Open \\ University, Islamabad, Pakistan
}

Correspondence: Aniqa Batool, Lecturer, Department of Environmental Sciences, Pir Mehr Ali Shah-Arid Agriculture University Rawalpindi, Shamsabad Murree Road Rawalpindi 46300, Pakistan,Email aniqabatool@uaar.edu.pk

Received: July 25, 2019 | Published: September 04, 2019

\section{Introduction}

Water is one of the utmost and fundamental requirements to sustain life on the planet earth. Being a universal solvent, water dissolves toxic organic and inorganic compounds that deteriorate its quality and influence consumer's health. Present day water sources, particularly surface waters are being polluted chiefly by domestic, agricultural, industrial, commercial wastes disposals in addition to natural contamination (e.g. trace metals) added due to the dissolution of natural substances and their subsequent transference in our flowing waters. ${ }^{1-5}$ Globally water contamination is major cause of diseases and deaths and the situation become worst in developing countries. ${ }^{1,6,7}$ Metal adulterations are mineral based which happen naturally or get in the watersheds through industrial discharges ${ }^{8}$ comprising copper chromium, iron, manganese and lead. ${ }^{9}$ Such high levels of these trace metals in water reveal their load in environment. Ingestion of higher amounts of metals through water route is of extreme significance in risk assessment studies in human health., ${ }^{4,10-12}$ and such substantial quantity may consequence in alarming adverse health effects ranging from shortness of breath to numerous types of cancers. ${ }^{13,14}$ Copper, lead and zinc enter the water, usually through pipelines, ${ }^{3,4,8,12,16,17}$ air pollution $^{18,19}$ and water stagnation in distribution system may cause significant rise in their levels. ${ }^{13}$

Lead is a potent neurotoxin and its occurrence in drinking water is the cause of various adverse health issues in humans. Acute poisoning of lead results in dis-functioning of kidneys, hypertension, brain, CNS, reproductive system, bones and blood enzyme changes. ${ }^{6,14,20,21}$
Higher copper concentration is immunotoxic; may cause metabolic and gastrointestinal complications and disturbs the liver and brain specifically in patients of Wilson's disease. . $14,20,22,23^{2}$

Higher chromium concentration is carcinogenic as well as genotoxic. ${ }^{924-26}$ Elevated levels of iron is connected with increasing risks for cancer, heart disease, and other illnesses like arthritis, endocrine problems, diabetes and also liver disease. ${ }^{21}$ Although manganese exists in water as a groundwater mineral yet may also enter through underground pollution sources. It may become obvious in tap water (at concentrations higher than $0.5 \mathrm{mg} / \mathrm{L}$ ) by imparting color, odor, or taste to the drinking water although health effects from $\mathrm{Mn}$ are not alarming until concentrations cross approximately $5 \mathrm{mg} / \mathrm{L} .{ }^{27}$

Zinc concentration in tap water can be much higher as a consequence of its leaching through piping and fittings. ${ }^{11,16,20,27}$ In humans higher concentration of $\mathrm{Zn}$ may cause demyelinating disease. ${ }^{23}$ Provision of safe drinking water to the public is one of the major concerns in the water sector in Pakistan. According to Farooq et al. ${ }^{28}$ approximately $40 \%$ of the total population has no access to potable water. WHO recommends that drinking water must be treated in order to make it free from toxic chemicals and pathogens. ${ }^{20}$ In Azad Jammu and Kashmir, more than eighty percent of illnesses have been recognized as due to the consumption of poor quality of water, supplied from surface and ground water sources. ${ }^{6}$ Assessed drinking water quality of $\mathrm{Bagh}^{18}$ and Rawalkot ${ }^{6}$ has also shown elevated contamination of trace metals and organic pollutants in this region. 


\section{Materials and methods}

\section{Study area}

Muzaffarabad (Lat:34.35 ; Long:73.47 ) is the capital of the Azad Jammu and Kashmir (Figure 1) situated at the convergence of the Neelum and Jhelum rivers, surrounded by mountains. District
Muzaffarabad covers an area of 2496sq.km. (19\% of the total area of the AJK state. The population of Muzaffarabad is 0.770 million comprising $21 \%$ of the total population of AJK. Average rainfall is $1300 \mathrm{~mm}$ with sub-tropical climate. ${ }^{29}$ The study area is bounded by Garri Dopatta in the East (24km away from city), Lohar Gali $(2 \mathrm{~km})$ in West, Pattika $(17 \mathrm{~km})$ in the North, and Kohala $(32 \mathrm{~km})$ in the South. ${ }^{29}$

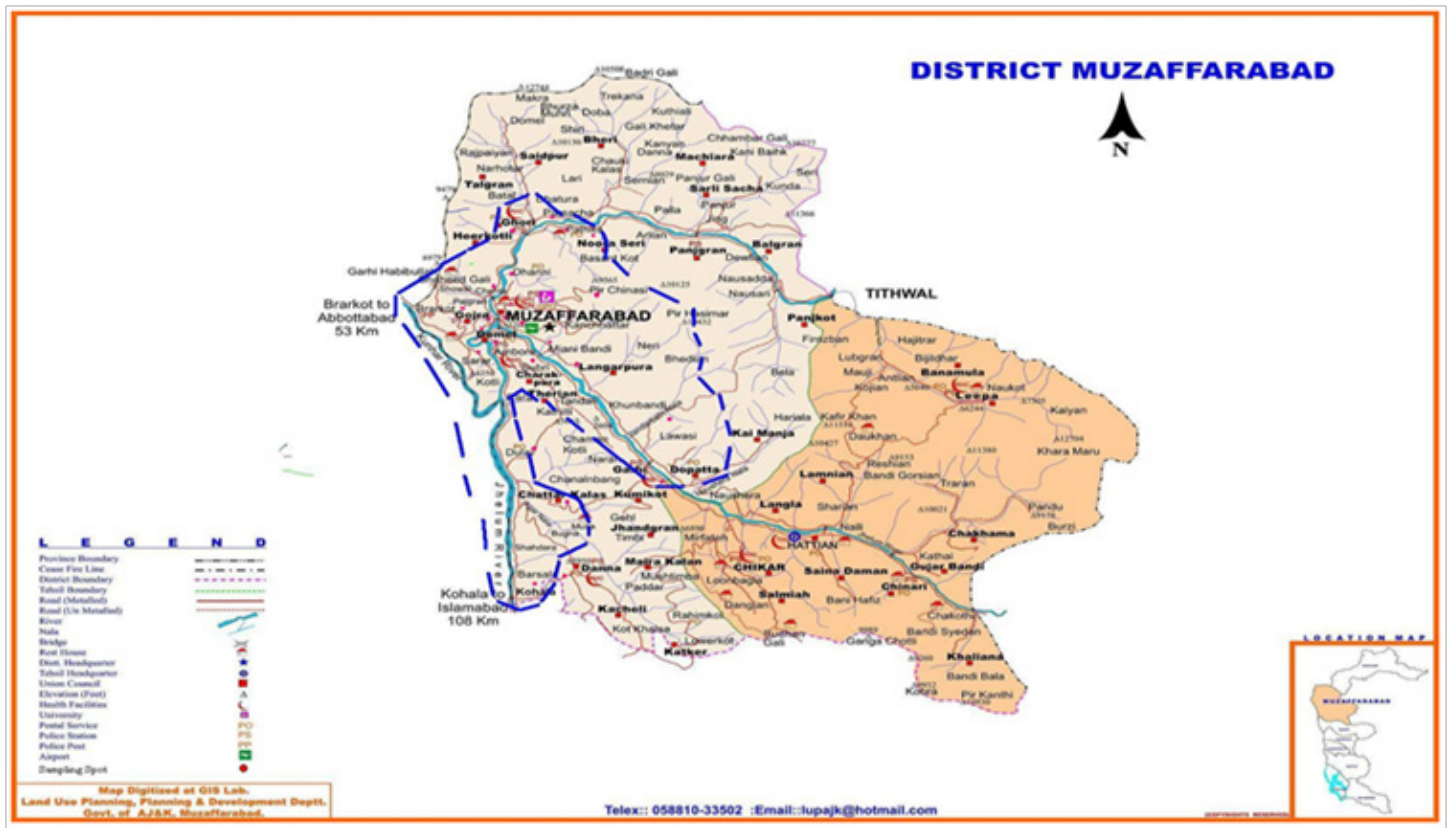

Figure I Map of the study area.

\section{Sample collection}

Samples were collected randomly from different house hold taps and natural spring sources of Muzaffarabad. Water flow was allowed for two to three minutes to discharge the stagnant water prior to collection of tap sample. Collecting bottles were pre washed with distilled water before collection. Bottles were completely filled with water and caps were replaced instantaneously. ${ }^{30}$ After collection samples bottles were kept in a cooler having ice slurry and transported to the laboratory.

\section{Analytical methods}

Copper, chromium, manganese, lead and zinc concentration in collected water samples were detected using atomic absorption spectrophotometer (AAS) (GBC 932plus) following Bartram \& Balance. ${ }^{31}$ The detection wavelength for $\mathrm{Cr}, \mathrm{Cu}, \mathrm{Fe}, \mathrm{Pb}, \mathrm{Mn}$ and $\mathrm{Zn}$ were $357.9 \mathrm{~nm}, 324.7 \mathrm{~nm}, 248.3 \mathrm{~nm}, 217.0 \mathrm{~nm}, 279.5 \mathrm{~nm}$ and $213.9 \mathrm{~nm}$ respectively. Standard solutions were prepared using commercially available Lab grad stock solutions of $1000 \mathrm{mg} / \mathrm{L}$ (Merk) of respective metals (3111B, APHA) ${ }^{32}$ Detection limit for each metal was calculated according to Fatoki and Awofolu ${ }^{33}$ and Javaid et al. ${ }^{6}$

\section{Statistical analysis}

Descriptive statistics was used for data analyses. T-test was used to compare findings of study with WHO and GoP guidelines value. MS Excel and Statistix (ver. 8.1) software were used to analyze data.

\section{Results and discussion}

The drinking water quality of Muzaffarabad was assessed by taking samples from tap and spring waters sources of Muzaffarabad. Total of fifty three drinking water samples were collected. People use surface water for variety of purposes including drinking water, cooking and basic hygiene, in addition to agricultural and industrial activities. The obtained results were compared with WHO and GOP standards established for drinking water. Result depicted that the drinking water of Muzaffarabad is tasteless, colorless and odorless meeting WHO and GOP limits and showing good aesthetic properties. Drinking water of other cities of Azad Jammu and Kashmir i.e. Rawalakot and Bagh was found to be colorless, tasteless and odorless. ${ }^{6,18}$ Metal concentrations varied in different drinking water of Muzaffarabad ranged from 0.0 to $0.718 \mathrm{mg} / \mathrm{L}(\mathrm{Fe})$. Out of 6 , maximum 5 metals detected in only one sample (Lachraat), whereas three metals detected in the majority $(43 \%)$ of the samples, followed by $2(23 \%), 4(15 \%)$ and $1(11 \%)$. Three drinking water samples $(6 \%)$ showed no detection of any metal (Appendix I).

\section{Chromium}

Chromium was detected in 16 drinking water samples whereas 8 samples showed no concentration of chromium. In 29 samples, the concentration remained below the detection limit (Figure 2). Detectable concentration ranged between $0.032( \pm 0.028) \mathrm{mg} / \mathrm{L}$ to 0.363 $(0.064) \mathrm{mg} / \mathrm{L}$ with mean value of $0.111( \pm 0.0224) \mathrm{mg} / \mathrm{L}$ (Appendix II). Maximum value found in Garhi Dupatta $0.363( \pm 0.064) \mathrm{mg} / \mathrm{L}$ 
followed by Kruli $0.207( \pm 0.017) \mathrm{mg} / \mathrm{L}$ and Dulai $0.194( \pm 0.020)$ $\mathrm{mg} / \mathrm{L}$, and minimum concentration detected in Pir Chinasi was 0.032 $( \pm 0.028) \mathrm{mg} / \mathrm{L}$ (Figure 3; Appendix I). Chromium showed equal distribution in tap and spring water. $30 \%$ spring water samples have shown $\mathrm{Cr}$ concentration as compared to $29 \%$ of tap water samples (Figure 4). Highly significant difference $(\mathrm{p}<0.01)$ was noted between the $\mathrm{Cr}$ concentration found in the collected samples and $\mathrm{WHO}$ and GOP allowable limits (Appendix III). Chromium concentration in drinking water may be due to natural and anthropogenic activities including painting, cooling tower water and chromate production. ${ }^{34}$ About $20 \%$ of the samples have raised concentration of $\mathrm{Cr}$ when compared with the standard value set by WHO (Figure 2). In other parts of the Pakistan e.g. KPK and Sindh, 75 percent and 25 percent drinking water samples had exceeded the guideline value of $\mathrm{Cr}$ respectively. ${ }^{35}$ Highly significant difference $(p<0.05)$ was observed between WHO limit and samples' chromium concentration. Nonpoint source pollution resulted in increased concentration of drinking water of Muzaffarabad. Its equal distribution in tap and spring waters of the study area showed equal environmental burden. Chromium concentration in spring water resulted from dissolution from parent rock strata, ${ }^{34,36}$ generally humans are exposed to an average of $0.2-2 \mu \mathrm{g}$ chromium per liter in drinking water through this natural erosion. ${ }^{26}$

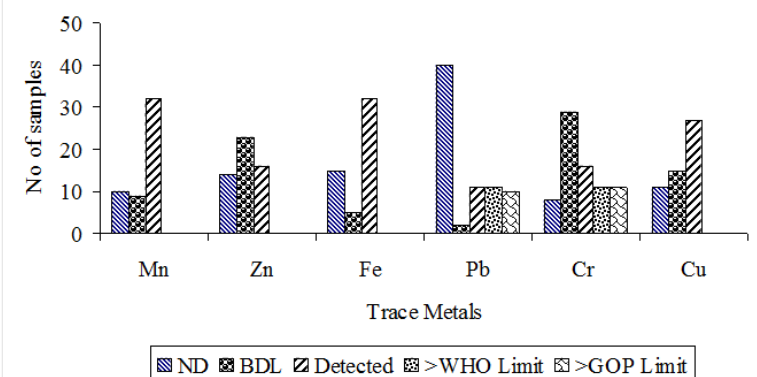

Figure 2 Status of different trace metals in drinking water samples of Muzaffarabad. (BDL)

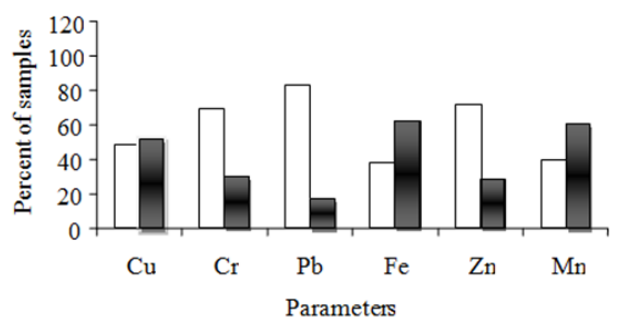

$\square$ Not Detected $\quad$ Detected

Figure 3 Detection percentage of different parameters in spring water of Muzaffarabad.

\section{Copper}

Copper detected in 27 drinking water samples while in 15 samples remained below the detection limit and in 11 samples it was not detected (Figure 2). Detectable concentration ranged between $0.038( \pm 0.043)$ to $0.211( \pm 0.017) \mathrm{mg} / \mathrm{L}$ with mean value of 0.1307 $( \pm 8.52 \mathrm{E}-03) \mathrm{mg} / \mathrm{L}$. Maximum $\mathrm{Cu}$ concentration observed in Pitika Park $0.211( \pm 0.017) \mathrm{mg} / \mathrm{L}$ followed by Mera Parsacha $0.205( \pm 0.010)$ $\mathrm{mg} / \mathrm{L}$ and Narool $0.180( \pm 0.010) \mathrm{mg} / \mathrm{L}$ and the lowest concentration was noted at Makri Plant $0.038( \pm 0.043) \mathrm{mg} / \mathrm{L}$. Fifty two percent samples of spring water and 43 percent samples of tap water were contaminated with copper (Figure 4). Non-significant difference was observed between the guideline values of WHO and GOP and copper concentration measured in the collected samples (Appendix III). Copper plumbing is a major source of increased copper in drinking water. ${ }^{18}$ The pitting of copper is usually linked with hard waters. ${ }^{37}$ The mean concentration of $\mathrm{Cu}(0.130 \mathrm{mg} / \mathrm{L})$ noted in collected samples of Muzaffarabad could be compared with average value of KPK $(0.20 \mathrm{mg} / \mathrm{L})$, Karachi $(0.31 \mathrm{mg} / \mathrm{L}),{ }^{34}$ Rawalakot $\left(0.70\right.$ to $2.79 \mathrm{mg} / \mathrm{L}^{6}$ and Bagh ( 1 to $4 \mathrm{mg} / \mathrm{L}) .{ }^{18}$ Maximum $\mathrm{Cu}$ concentration in tap water was reported to be $1.2 \mathrm{mg} / \mathrm{L}$ in Chile, $4.8 \mathrm{mg} / \mathrm{L}$ in USA, $1.9 \mathrm{mg} / \mathrm{L}$ in India, ${ }^{11} 0.01 \mathrm{mg} / \mathrm{L}$ in Nigeria. ${ }^{3-5}$ and $4.6 \mathrm{mg} / \mathrm{L}$ in Hong Kong. ${ }^{10}$ In our study sixty two percent spring water samples and fifty seven percent tap water samples showed $\mathrm{Cu}$ concentration. This indicated the dissolution of metal in both types of water through common source.

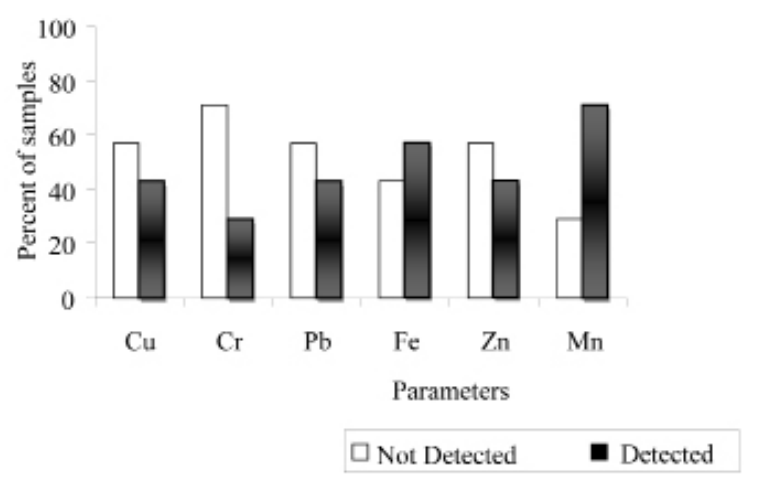

Figure 4 Detection percentage of different parameters in tap water of Muzaffarabad.

\section{Iron}

Iron found in thirty two drinking water samples and only five water samples showed concentration of iron below the detection limit while it was not present in fifteen samples (Figure 2). Detectable iron concentration ranged from $0.096( \pm 0.048) \mathrm{mg} / \mathrm{L}$ to $0.718( \pm 0.065)$ $\mathrm{mg} / \mathrm{L}$ with mean concentration of $0.279( \pm 0.0315) \mathrm{mg} / \mathrm{L}$ (Appendix II). Maximum Fe concentration was found in Narool samples i.e. 0.718 $( \pm 0.065) \mathrm{mg} / \mathrm{L}$ followed by Malsi $0.661( \pm 0.059) \mathrm{mg} / \mathrm{L}$ and Barsala $0.625( \pm 0.028) \mathrm{mg} / \mathrm{L}$. Minimum concentration was detected in Makri plant $0.096( \pm 0.048) \mathrm{mg} / \mathrm{L}$ (Appendix I). No significant difference $(p>0.05)$ was observed between sample concentration of iron and WHO guideline, that showed the concentration of iron in drinking water falls within WHO and GOP permissible limits (Appendix III). Iron was equally distributed in $57 \%$ and $62 \%$ samples of tap and spring water of the study area respectively (Figure 4). Iron is abundantly found element in the earth's crust, although present usually in minor concentrations in natural water. The formation of ferric precipitate makes drinking water objectionable. None of the water sample crossed WHO limit for iron in the collected samples which could be compared with surface water of KPK and Sindh where $25 \%$ and $100 \%$ samples had crossed the critical WHO level for Fe respectively. ${ }^{35}$ The concentration of Fe fluctuated between $0.01-1.29 \mathrm{mg} / \mathrm{L}$ in water samples of KPK and $0.13-2.91 \mathrm{mg} / \mathrm{L}$ in Karachi, ${ }^{35} 5.3-12.18 \mathrm{mg} / \mathrm{L}$ in Nigeria $^{3-5}$ and 0.01 to $18.86 \mathrm{mg} / \mathrm{L}$ in Rift valley Ethiopia. ${ }^{38}$

\section{Lead}

Lead detected in 11 samples while its concentration remained below the detection limit in 2samples (Figure 2). The lead 
concentration ranged between $0.029( \pm 0.008) \mathrm{mg} / \mathrm{L}$ to $0.665( \pm 0.178)$ $\mathrm{mg} / \mathrm{L}$ with mean concentration of $0.1612( \pm 0.0542) \mathrm{mg} / \mathrm{L}$ (Appendix I). Maximum lead concentration was in Dulai $0.665( \pm 0.178) \mathrm{mg} / \mathrm{L}$ followed by Bandi Kareem Haider $0.293( \pm 0.039) \mathrm{mg} / \mathrm{L}$ and Jalalabad $0.129( \pm 0.123) \mathrm{mg} / \mathrm{L}$ and minimum concentration $0.029( \pm 0.008)$ $\mathrm{mg} / \mathrm{L}$ was detected in Sundh Gali, Muzaffarabad. Lead was not present in 40 drinking water samples (Appendix I). Highly significant difference $(p<0.01)$ was witnessed between the guideline value of lead and drinking water concentration found in the samples of Muzaffarabad (Appendix III). Ten drinking water samples showed higher $\mathrm{Pb}$ concentration as compared to the GOP guidelines value for drinking water in Pakistan (Appendix I). The common sources of lead are lead-based paints, traditional remedies, cosmetics and leaded petrol. ${ }^{5,39}$ Lead was detected in 43 percent samples of tap water which was higher than spring water samples. The noted concentration of $\mathrm{Pb}$ in our study $(0.029-0.665 \mathrm{mg} / \mathrm{L})$ was higher than the surface water of KPK $(0.02-0.38 \mathrm{mg} / \mathrm{L})$ and Karachi $(0.09-0.32 \mathrm{mg} / \mathrm{L})^{35}$ and lower than Rawalakot $(1.82 \text { and } 4.66 \mathrm{mg} / \mathrm{L})^{6}$ and Bagh $(<3$ to $7 \mathrm{mg} / \mathrm{L}) .{ }^{18} \mathrm{Lead}$ concentration was significant when compared to WHO guidelines value.

In the study area, there is no identified point source of metals contamination. Higher concentration of lead in some of the water samples is due to atmospheric pollution because $\mathrm{Pb}$ is one of the important environmental toxin which is documented by other studies. $^{3-6,18,40}$ Atmospheric concentration could rise due to use of leaded petrol which is very common practice in Pakistan and Azad Jammu and Kashmir. ${ }^{6,41}$ Higher concentration of $\mathrm{Pb}$ in tap water of Dolet colony $0.089( \pm 0.019) \mathrm{mg} / \mathrm{L}$ and Domel $0.089( \pm 0.020) \mathrm{mg} / \mathrm{L}$ resulted by corrosion from distribution pipes. Corrosion is the chief source of $\mathrm{Pb}$ contamination in drinking water. ${ }^{4-6,35,40}$

\section{Manganese}

Manganese detected in thirty two samples. Detectable concentration of $\mathrm{Mn}$ ranged between $0.013( \pm 0.004) \mathrm{mg} / \mathrm{L}$ and $0.246( \pm 0.065) \mathrm{mg} / \mathrm{L}$ with mean value of $0.0684( \pm 0.0542) \mathrm{mg} / \mathrm{L}$ (Appendix II). Highest concentration was detected in Garhi Dupatta $0.246( \pm 0.065) \mathrm{mg} / \mathrm{L}$ followed by Tali Mandi $0.224( \pm 0.037) \mathrm{mg} / \mathrm{L}$, Majhoi $0.206( \pm 0.037)$ $\mathrm{mg} / \mathrm{L}$ and lowest Mn concentration was in Makri Plant $0.013( \pm 0.004)$ (Appendix I). There was no detection of this metal in 10 samples while in nine samples concentration was below the detection limit (Figure 2). Non-significant difference was observed between the concentration of $\mathrm{Mn}$ in samples and guideline value established by $\mathrm{WHO}^{20}$ and GOP. ${ }^{42}$ Manganese concentration range in drinking water of Muzaffarabad varied from 0.031 to $0.246 \mathrm{mg} / \mathrm{L}$ which was less than the drinking water of Rawalakot (0.54 to $4.73 \mathrm{mg} / \mathrm{L}),{ }^{6} \mathrm{Bagh}(0.7-2 \mathrm{mg} /$ $\mathrm{L})^{18}$ and KPK $(0.01-1.11 \mathrm{mg} / \mathrm{L}) .^{35}$ Manganese showed almost identical distribution pattern in tap and spring water samples. It was detected in 71 percent and 61 percent samples taken from tap and spring water respectively. Non-significant difference was observed between guideline values set by WHO and GOP and manganese concentration in the collected water samples. In our study Mn concentration is attributed to under-ground pollution sources.

\section{Zinc}

Zinc observed in 16 samples and remained below the detection limit in twenty three samples (Figure 2). Detectable concentration of zinc ranged from $0.058( \pm 0.021) \mathrm{mg} / \mathrm{L}$ to $0.405( \pm 0.269) \mathrm{mg} / \mathrm{L}$ with mean concentration of $0.144( \pm 0.0238) \mathrm{mg} / \mathrm{L}$ (Appendix II). Highest concentration of zinc detected in Plate tap was $0.408( \pm 0.269)$ $\mathrm{mg} / \mathrm{L}$ followed by Police Line $0.265(0.239) \mathrm{mg} / \mathrm{L}$ and Makri Plant $0.231( \pm 0.160) \mathrm{mg} / \mathrm{L}$, whereas lowest $\mathrm{Zn}$ concentration was in Malsi
$0.058( \pm 0.021) \mathrm{mg} / \mathrm{L}$ (Appendix I). There was no detection of $\mathrm{Zn}$ in fourteen samples of the study area (Figure 2). Concentration of $\mathrm{Zn}$ showed non-significant difference when compared to the guideline value of WHO (Appendix III). Zinc is also among the most common elements in the earth's crust. ${ }^{46,43}$ Zinc compounds are widely used in paints, ceramics, batteries, fabrics, sun block etc. and released in large quantities during production. ${ }^{27,43}$ The measured values for $\mathrm{Zn}(0.05-0.405 \mathrm{mg} / \mathrm{L})$ in drinking water could be compared with Bagh $(1-3 \mathrm{mg} / \mathrm{L}),{ }^{18}$ Nigeria $(0.3-0.49 \mathrm{mg} / \mathrm{L})^{3-5}$ Rawalakot $(0.56$ to $2.69 \mathrm{mg} / \mathrm{L})^{6}$ and Rift valley Ethiopia $(0.01$ to $5.14 \mathrm{mg} / \mathrm{L}){ }^{38}$ Zinc was distributed more frequently in tap water than spring water. Forty three percent samples of tap water and 28 percent samples of spring water were contaminated with $\mathrm{Zn}$. Its concentration in tap water was due to leaching from piping and fittings. ${ }^{6,18,44}$ No significant difference was observed between WHO guideline value and $\mathrm{Zn}$ concentration in the drinking water of Muzaffarabad.

\section{Conclusion}

On the bases of results, following conclusions are made, that the nature of parameters studied in which concentration exceeded from the WHO and GOP guideline values indicated the elevated concentration is attributed to natural as well as anthropogenic activities. Excess lead concentration in tap water indicated mostly corrosion of faucets or water utility pipes in distribution system. Levallois et al. ${ }^{14}$ supported the view that lead can be released into water from lead-containing service lines, leaded pipes, solders, and faucets in buildings. In spring water, it was due to environmental pollution such as automobiles and welding material. Chromium concentration ranged from below the detection limit to higher than permissible limit. In spring water, $\mathrm{Cr}$ concentration is added through sediments whereas tap water concentration showed environmental burden of this metal. Metals concentration like iron, zinc, copper and manganese observed within the range of WHO limits.

\section{Acknowledgments}

None.

\section{Conflicts of interest}

The authors declare that there are no conflicts of interest.

\section{Funding}

None.

\section{References}

1. Zahoorullah T, Akhtar T, Akhtar, et al. Quality of drinking water in rural Peshawar. Pak J Med Res. 2003;42(3):85-89.

2. Beamonte E, Bermudez JD, Casino A, et al. A statistical study of the quality of surface water intended for human consumption near Valencia (Spain). J Env Manage. 2007;83(3):307-314.

3. Raimi Morufu Olalekan, Sabinus CE. An Assessment of Trace Elements in Surface and Ground Water Quality in the Ebocha-Obrikom Oil and Gas Producing Area of Rivers State, Nigeria. International Journal for Scientific and Engineering Research (Ijser). 2017;8(6).

4. Morufu Raimi, Clinton Ezekwe. Assessment of Trace Elements in Surface and Ground Water Quality (2017). Lambert Academic Publishing. 2017.

5. Olalekan RM, Adedoyin O, Odubo TV. Measures of harm from heavy metal content (Lead and Cadmium) in Women Lipstick and Lipgloss in Yenagoa Metropolis, Bayelsa state, Nigeria. International Journal of Petrochemistry and Research. 2018;2(3):236-242. 
6. Javaid S, Shah SGS, Chaudhary AJ, et al. Assessment of trace metal contamination of drinking water in the Pearl valley Azad Jammu and Kashmir. Clean. 2008;36(2):216-221.

7. Raimi MO, Pigha Tarilayun K, Ochayi EO. Water-Related Problems and Health Conditions in the Oil Producing Communities in Central Senatorial District of Bayelsa State. Imperial Journal of Interdisciplinary Research (IJIR). 2017;3(6)

8. Afzal BM. Drinking water and women's health. J Midwifery \& Wom Health. 2006;51(1):12-18.

9. Paustenbach DJ, Finley BL, Mowat FS. Human health risk and exposure assessment of chromium (VI) in tap water. J Toxicol Environ Health A. 2003;66(14):1295-1339.

10. Cheung KC, Poon BHT, Lan CY, et al. Assessment of metal and nutrient concentrations in river water and sediment collected from the cities in the Pearl River Delta, South China. Chemosphere. 2003;52(9):14311440

11. Xu P, Huang $\mathrm{S}$, Wang $\mathrm{Z}$, et al. Daily intakes of copper, zinc and arsenic in drinking water by population of Shanghai, China. Sci Total Envir. 2005;362(1-3):50-55.

12. Olalekan RM, Omidiji AO, Nimisngha D, et al. Health Risk Assessment on Heavy Metals Ingestion through Groundwater Drinking Pathway for Residents in an Oil and Gas Producing Area of Rivers State, Nigeria. Open Journal of Yangtze Gas and Oil. 2018;3:191-206.

13. Kavcar P, Sofuoglu A, Sofuoglu SC. A health risk assessment for exposure to trace metals via drinking water ingestion pathway. Inter $J$ Hyg Environ Health. 2009;212(2):216-227.

14. Levallois P, Barn P, Valcke M, et al. Public Health Consequences of Lead in Drinking Water. Current Environmental Health Reports. 2018:5:255-262.

15. Pettersson R, Rasmussen F. Daily Intake of Copper from Drinking Water among Young Children in Sweden Author(s): Environ. Health Persp. 1999;107(6):441-446.

16. Reyes A, Letelier MV, De la Iglesia, et al. Microbiologically induced corrosion of copper pipes in low-ph water. Intern Biodeterio Biodegrad. 2008;61(2):135-141.

17. Olalekan RM, Adedoyin OO, Ayibatonbira A, et al. "Digging deeper' evidence on water crisis and its solution in Nigeria for Bayelsa state: a study of current scenario. International Journal of Hydrology. 2019;3(4):244-257

18. Sabir SM, Khan SW, Gardezi SS. Effect of environmental pollution on quality of water in district Bagh, Azad Kashmir. Pak J Biol Sci. 2003;6(9):831-835.

19. Raimi Morufu Olalekan, Adeolu Adedotun Timothy, Enabulele Chris E, et al. Assessment of Air Quality Indices and its Health Impacts in Ilorin Metropolis, Kwara State, Nigeria. Science Park Journals of Scientific Research and Impact. 2018;4(4):060-074.

20. WHO. Guideline for Drinking Water Ouality. $3^{\text {rd }}$ ed. (Electronic Source). 2006.

21. Elci L, Kartal AA, Soylak M. Solid phase extraction method for the determination of iron, lead and chromium by atomic absorption spectrometry using Amberite XAD-2000 column in various water samples. J Hazard Mater. 2008;153(1-2):454-461.

22. Bigazzi PE. Metals and Kidney Autoimmunity. Environ Health Persp. 1999;107(5):753-765

23. Mora ACM, Quhae MC, Sanchez 1. Survey of trace metals in drinking water supplied to rural populations in the eastern Llanos of Venezuela. $J$ Environ Manage. 2008;90(2):752-759.

24. Pereira L Al, IG deAmorim, da Silva JB. Development of methodologies to determine aluminum, cadmium, chromium and lead in drinking wate by ET AAS using permanent modifiers. Talanta. 2004;64(2):395-400.
25. De Flora S, D'Agostini F, Balansky R, et al. Lack of genotoxic effects in hematopoietic and gastrointestinal cells of mice receiving chromium (VI) with the drinking water. Mutat Res. 2008;659(1-2):60-67.

26. Moffat I, Martinova N, Seidel C, et al. Hexavalent Chromium in Drinking Water. Journal AWWA. 2018;110(5):E22-E35.

27. Dimirkou A, Doula MK. Use of clinoptilolite and an Fe overexchanged clinoptilolite in $\mathrm{Zn}^{2+}$ and $\mathrm{Mn}^{2+}$ removal from drinking water. Desalination. 2008;224(1-3):280-292.

28. Farooq S, Hashmi I, Qazi IA, et al. Monitoring of Coliforms and chlorine residual in water distribution network of Rawalpindi, Pakistan. Environ. Monit Asses. 2008;140(1-3):339-347.

29. AJK. Azad Jammu and Kashmir Guide Book. Tourism Department, AJK. 2019.

30. Muneer B, Latif Q, Ahmed K, et al. Microbiological assessment of drinking water supply in University of the Punjab. Pak J Zool. 2000;33(1):61-68

31. Bartram J, Balance R. Water Quality Monitoring - A Practical Guild to the Design and Implementation of Freshwater Quality Studies and Monitoring Program. UNEP/WHO. 1996.

32. APHA. Standard Methods for the Examination of Water and Wastewater $21^{\text {st }}$ ed. APHA, Washington. 2005.

33. Fatoki $\mathrm{O}$, Awofolu $\mathrm{R}$. Levels of $\mathrm{Cd}, \mathrm{Hg}$ and $\mathrm{Zn}$ in some surface waters from the Eastern Cape Province, South Africa. Water SA. 2003;29(4):375-380.

34. Rafael AI, Almeida A, Santos P, et al. A role for transforming growth factor- $\beta$ apoptotic signaling pathway in liver injury induced by ingestion of water contaminated with high levels of $\mathrm{Cr}(\mathrm{VI})$. Toxicol Applied Pharmacol. 2007;224(2):63-173.

35. Haq M, Khattak RA, Puno HK, et al. Surface and ground water contamination in NWFP and Sindh provinces with respect to trace elements. Inter J Agri and Bio. 2005;7(2):214-217.

36. Karavoltsos S, Aikaterini S, Nikolaos M, et al. Evaluation of the quality of drinking water in region of Greece. Desalination. 2008;224(13):317-329.

37. Tiwary RK, Kumari B, Singh DB. Water Quality Assessment and Correlation Study of Physico-Chemical Parameters of Sukinda Chromite Mining Area, Odisha, India. Environmental Pollution. 2017;357-370.

38. Reimann C, Bjorvatn, Frengstad, et al. Drinking water quality in the Ethiopian section of the East African Rift Valley I, data and health aspects. Sci Total Environ. 2003;311(1-3):65-80.

39. Khan FJ, Javed Y. Delivering Access to Safe Drinking Water and Adequate Sanitation in Pakistan. PIDE Working Papers. 2007.

40. Ahmed R. Impact of environmental pollution in Rawalpindi and Islamabad. 24 $4^{\text {th }}$ WEDC conference; Sanitation and Water for All. Islamabad. 1998;157-158.

41. Farooq Y, Hussain MM, Aleem SB, et al. Lead intoxication: The extent of problem and its management. Pak J Physiol. 2008;4(2):36-41.

42. GOP. Quality drinking water standards for Pakistan includes legislating, implementing and monitoring framework. Ministry of Health and World Health Organization. 2008.

43. Henry Olawale Sawyerr, Morufu Olalekan Raimi, Adedotun Timothy Adeolu, et al. Measures of Harm from Heavy Metal Pollution in Battery Technicians' Workshop within Ilorin Metropolis, Kwara State, Nigeria. Scholink Communication, Society and Media. 2019;2(2):17.

44. Peng S, Wang W, Chen J. Partitioning of trace metals in suspended sediments from Huanghe and Changjiang rivers in eastern China. Water Air and Soil Pollut. 2003;148(1-4):243-258. 


\section{Appendices}

Appendix I Concentration of trace metals in drinking water samples in Muzaffarabad AJK.

\begin{tabular}{|c|c|c|c|c|c|c|c|c|c|c|c|c|c|}
\hline \multirow[b]{4}{*}{$\begin{array}{l}\text { S. } \\
\text { No. }\end{array}$} & \multicolumn{13}{|c|}{ Trace metals (Means $\pm S D$ ) } \\
\hline & \multirow{3}{*}{$\begin{array}{l}\text { WHO guideline } \\
\text { value } \\
\text { GoP guideline value }\end{array}$} & \multirow{2}{*}{\multicolumn{2}{|c|}{$\begin{array}{l}\mathrm{Cu}(3 \mathrm{mg} / \mathrm{L}) \\
\mathrm{Cu}(2 \mathrm{mg} / \mathrm{L})\end{array}$}} & \multirow{2}{*}{\multicolumn{2}{|c|}{$\begin{array}{l}\mathrm{Cr}(0.05 \mathrm{mg} / \mathrm{L}) \\
\mathrm{Cr}(0.05 \mathrm{mg} / \mathrm{L})\end{array}$}} & \multicolumn{2}{|c|}{$\mathrm{Pb}(0.01 \mathrm{mg} / \mathrm{L})$} & \multicolumn{2}{|c|}{$\mathrm{Fe}(\mathrm{I}-3 \mathrm{mg} / \mathrm{L})$} & \multicolumn{2}{|c|}{$\mathrm{Zn}(3 \mathrm{mg} / \mathrm{L})$} & \multicolumn{2}{|c|}{$M n(0.5 m g / L)$} \\
\hline & & & & & & $\mathrm{Pb}(0.0$ & $\mathrm{mg} / \mathrm{L})$ & & & $\operatorname{Zn}(5 n$ & $g / L)$ & $M n(0$. & $\mathrm{mg} / \mathrm{L})$ \\
\hline & & & & & & & & & & & & & \\
\hline $\mathrm{I}$. & Bandi Kareem Haider & ND & & ND & & 0.293 & -0.039 & $\mathrm{BDL}$ & & ND & & BDL & \\
\hline 2. & Bandway & 0.133 & -0.006 & 0.179 & -0.066 & ND & & ND & & ND & & 0.127 & -0.023 \\
\hline 3. & Bansara & ND & & ND & & ND & & BDL & & ND & & ND & \\
\hline 4. & Barsala & 0.043 & -0.006 & ND & & ND & & 0.625 & -0.028 & BDL & & $\mathrm{BDL}$ & \\
\hline 5. & Chall Pani & 0.082 & -0.012 & ND & & ND & & 0.197 & -0.026 & $\mathrm{BDL}$ & & 0.084 & -0.009 \\
\hline 6. & Channal Bang & 0.067 & -0.031 & $\mathrm{BDL}$ & & ND & & 0.254 & -0.014 & 0.098 & -0.017 & 0.023 & -0.008 \\
\hline 7. & Chattar Klass & 0.152 & -0.009 & ND & & ND & & 0.504 & -0.039 & ND & & 0.09 & -0.019 \\
\hline 8. & Darbar & BDL & & ND & & ND & & 0.107 & -0.04 & 0.19 & -0.269 & 0.02 & -0.024 \\
\hline 9. & Dhanni Mai Sahiba & 0.126 & -0.007 & ND & & ND & & 0.342 & -0.036 & BDL & & 0.08 & -0.015 \\
\hline 10. & Doba Sayedan & 0.126 & -0.004 & ND & & ND & & 0.382 & -0.031 & $\mathrm{BDL}$ & & 0.097 & -0.021 \\
\hline II. & Dolet Colony (tap) & BDL & & 0.07 & -0.014 & 0.089 & -0.019 & BDL & & BDL & & BDL & \\
\hline 12. & Domail (tap) & ND & & ND & & 0.089 & -0.02 & $\mathrm{BDL}$ & & ND & & 0.03 & -0.023 \\
\hline 13. & Dulai & $\mathrm{BDL}$ & & 0.194 & -0.02 & 0.665 & -0.178 & 0.116 & -0.099 & BDL & & 0.014 & -0.01 \\
\hline 14. & Garhi Dupatta & 0.17 & -0.007 & 0.363 & -0.064 & ND & & BDL & & ND & & 0.246 & -0.065 \\
\hline 15. & Ghorri & ND & & 0.082 & -0.034 & 0.12 & -0.082 & 0.144 & -0.058 & ND & & 0.028 & -0.028 \\
\hline 16. & Gorri & 0.113 & -0.005 & ND & & ND & & 0.323 & -0.033 & 0.172 & -0.055 & ND & \\
\hline 17. & Hasan Abad & ND & & $\mathrm{BDL}$ & & ND & & $\mathrm{BDL}$ & & 0.079 & -0.098 & 0.018 & -0.016 \\
\hline 18. & Hassan Galian & ND & & 0.087 & -0.055 & ND & & $\mathrm{BDL}$ & & 0.123 & -0.109 & 0.029 & -0.05 \\
\hline 19. & Hundi Peran & 0.12 & -0.008 & ND & & ND & & 0.228 & -0.017 & $\mathrm{BDL}$ & & ND & \\
\hline 20. & Jalalabad & $\mathrm{BDL}$ & & ND & & 0.129 & -0.123 & 0.128 & -0.038 & 0.095 & -0.124 & $\mathrm{BDL}$ & \\
\hline 21. & Kaju & 0.098 & -0.01 & $\mathrm{BDL}$ & & ND & & $\mathrm{BDL}$ & & ND & & 0.047 & -0.01 \\
\hline 22. & Kal Panah & 0.106 & -0.016 & 0.035 & -0.01 & ND & & 0.397 & -0.014 & $\mathrm{BDL}$ & & 0.175 & -0.042 \\
\hline 23. & Khashkar & $\mathrm{BDL}$ & & 0.075 & -0.001 & ND & & 0.129 & -0.017 & 0.09 & -0.031 & 0.013 & -0.011 \\
\hline 24. & Kohala & $\mathrm{BDL}$ & & ND & & 0.096 & -0.007 & 0.148 & -0.044 & 0.19 & -0.043 & 0.022 & -0.018 \\
\hline 25. & Kruli & 0.099 & -0.012 & 0.207 & -0.017 & ND & & 0.516 & -0.02 & BDL & & 0.125 & -0.018 \\
\hline 26. & Lachraat & 0.111 & -0.012 & 0.062 & -0.012 & ND & & 0.465 & -0.025 & 0.061 & -0.026 & 0.015 & -0.004 \\
\hline 27. & Langerpura & 0.151 & -0.017 & ND & & ND & & ND & & ND & & ND & \\
\hline 28. & Lower Chatter & $\mathrm{BDL}$ & & $\mathrm{BDL}$ & & ND & & $\mathrm{BDL}$ & & ND & & $\mathrm{BDL}$ & \\
\hline 29. & Madina Market & 0.112 & -0.013 & ND & & 0.114 & -0.021 & $\mathrm{BDL}$ & & ND & & 0.019 & -0.009 \\
\hline 30. & Majhoi & 0.178 & -0.005 & ND & & ND & & 0.206 & -0.018 & ND & & 0.206 & -0.037 \\
\hline 31. & Makri Plant & 0.038 & -0.043 & $\mathrm{BDL}$ & & ND & & 0.096 & -0.048 & 0.231 & -0.16 & 0.013 & -0.004 \\
\hline 32. & Malsi & 0.169 & -0.006 & ND & & ND & & 0.661 & -0.059 & 0.058 & -0.021 & ND & \\
\hline 33. & Mera Parsacha & 0.205 & -0.01 & ND & & ND & & 0.102 & -0.032 & ND & & 0.112 & -0.011 \\
\hline 34. & Narool (tap) & 0.18 & -0.01 & ND & & BDL & & 0.718 & -0.046 & BDL & & 0.029 & -0.006 \\
\hline 35. & Pajgran & ND & & 0.043 & -0.018 & ND & & $\mathrm{BDL}$ & & $\mathrm{BDL}$ & & ND & \\
\hline 36. & Patti Naka & ND & & ND & & ND & & ND & & BDL & & 0.022 & -0.028 \\
\hline 37. & Pir Chinasi & ND & & 0.032 & -0.028 & ND & & BDL & & 0.067 & -0.011 & BDL & \\
\hline
\end{tabular}


Table continued

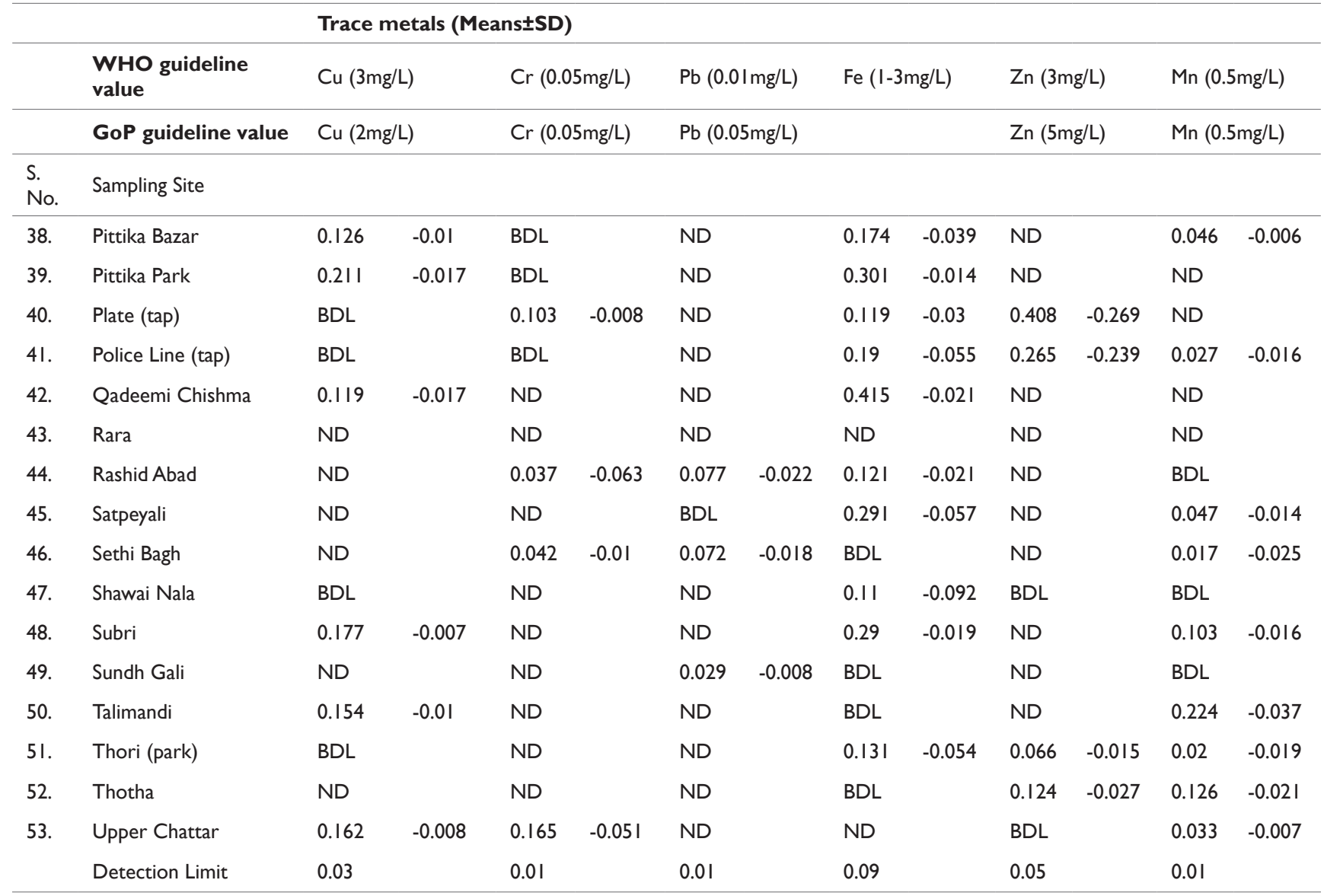

ND, not detected; BDL, below detection limit

Appendix II Descriptive statistics for different study parameters.

\begin{tabular}{lllllllll}
\hline Parameters & N & Mean & SD & SE Mean & C.V. & Min. & Med. & Max. \\
\hline $\mathrm{Cr}(\mathrm{mg} / \mathrm{L})$ & 16 & 0.111 & 0.0898 & 0.0224 & 80.876 & 0.032 & 0.0785 & 0.363 \\
$\mathrm{Cu}(\mathrm{mg} / \mathrm{L})$ & 27 & 0.1307 & 0.0443 & $8.52 \mathrm{E}-03$ & 33.879 & 0.038 & 0.126 & $0.21 \mathrm{I}$ \\
$\mathrm{Fe}(\mathrm{mg} / \mathrm{L})$ & 32 & 0.2791 & 0.1784 & 0.0315 & 63.919 & 0.096 & 0.217 & 0.718 \\
$\mathrm{Mn}(\mathrm{mg} / \mathrm{L})$ & 34 & 0.0684 & 0.0656 & 0.0112 & 95.84 & 0.013 & 0.0315 & 0.246 \\
$\mathrm{~Pb}(\mathrm{mg} / \mathrm{L})$ & 11 & 0.1612 & 0.1798 & 0.0542 & 111.56 & 0.029 & 0.096 & 0.665 \\
$\mathrm{Zn}(\mathrm{mg} / \mathrm{L})$ & 16 & 0.1448 & 0.0951 & 0.0238 & 65.683 & 0.058 & 0.096 & 0.408 \\
\hline
\end{tabular}

Appendix III One sample t-test comparing the means of the parameters with WHO parametric values.

\begin{tabular}{|c|c|c|c|c|c|c|c|}
\hline \multirow[b]{2}{*}{ Parameter } & \multirow{2}{*}{$\begin{array}{l}\text { WHO } \\
\text { guidelines }\end{array}$} & \multirow[b]{2}{*}{$\mathbf{N}$} & \multirow[b]{2}{*}{ Mean } & \multirow[b]{2}{*}{ SE } & \multicolumn{2}{|c|}{$95 \%$ Conf interval } & \multirow[b]{2}{*}{ t- value } \\
\hline & & & & & Lower & Upper & \\
\hline Copper & $2 \mathrm{mg} / \mathrm{L}$ & 27 & 0.1307 & $8.519 \mathrm{E}-03$ & 0.1132 & 0.1482 & -219.42 \\
\hline Chromium & $0.05 \mathrm{mg} / \mathrm{L}$ & 16 & 0.1110 & 0.0224 & 0.0632 & 1.588 & $2.72^{* *}$ \\
\hline Iron & $10 \mathrm{mg} / \mathrm{L}$ & 32 & 0.2791 & 0.0315 & 0.2148 & 0.343 & -86.29 \\
\hline Manganese & $0.5 \mathrm{mg} / \mathrm{L}$ & 34 & 0.0684 & 0.0112 & 0.0456 & 0.0913 & -38.36 \\
\hline Lead & $0.01 \mathrm{mg} / \mathrm{L}$ & 11 & 0.1612 & 0.0542 & 0.404 & 0.2820 & $2.79 * *$ \\
\hline Zinc & $2 \mathrm{mg} / \mathrm{L}$ & 16 & 0.1448 & 0.0238 & $0.094 \mid$ & 0.1955 & -78.02 \\
\hline
\end{tabular}

SE, standard deviation; ** Highly significant 